\title{
The effect of magnesium pemoline on learning an active avoidance-passive avoidance discrimination'
}

\author{
THOMAS C. CHASE ${ }^{2}$ AND ROBERT A. RESCORLA \\ YALE UNIVERSITY
}

Magnesium pemoline failed to facilitate the learning of an active avoidance - passive avoidance discrimination. The sensitizing and stimulant properties of the drug disrupted learning of the discrimination when a buzzer was used as the cue for passive avoidance.

Plotnikoff (1966) has reported that magnesium pemoline, a mild central nervous system stimulant. enhances performance of a conditioned avoldance response during both acquisition and retention. He interpreted this finding in terms of learning improvement, relating it to the report of Glasky \& Simon (1966) that magneslum pemoline stimulates in vitro RNA polymerases in rat brain. However, further studies (Powell et al, 1967a, b; Lubar et al, 1967) have indicated that the drug acts as a stimulant even at low dosages. Such a stimulant effect could itself produce the different rates of acquisition that Plotnikoff had reported. Furthermore, Beach \& Kimble (1967) found that administration of magnesium pemoline led to a lesser decrease in activity in an habituation situation, and also produced a more sustained responsivity to the sound of a buzzer. Again the implication is that magnesium pemoline affects performance, not learning and memory.

This study was designed to distinguish between a learning and an increased activity and/or responsivity account of Plotnikoff's results. It was reasoned that if magnesium pemoline facilitates learning, animals receiving the drug should learn an active avoidancepassive avoidance discrimination faster than controls. If magnesium pemoline serves only as a stimulant-or sensitizer, it should retard discrimination learning. More inappropriate responses would be made in the presence of the conditioned stimulus for passive avoidance, and avoidance responses would have shorter latencies.

Subjects

Twenty-four male Sprague-Dawley rats were run in two squads, four months apart. The $12 \mathrm{Ss}$ in the first squad weighed between 400 and $480 \mathrm{~g}$, those in the second squad weighed between 378 and $414 \mathrm{~g}$. Since no significant difference in performance was found between squads $(F=1.31, d f=1 / 16)$ and their data was combined for analyses.

\section{Apparatus}

The apparatus was a jump-out box with a grid bar floor and an escape platform built into one wall, modeled after that used by Plotnikoff. Three 1/4 in. stainless rods spaced $3 / 4$ in. apart were mounted under the escape platform to aid the animal in reaching the plat- form. A removable clear Plexiglas door could make the escape platform and the rods inaccessable during the negative conditioned stimulus. On the wall opposite the escape platform, $18 \mathrm{in}$. above the grid floor, a buzzer and $71 / 2 \mathrm{~W}$ bulb and socket were mounted. The light could be made to flash 5 times per sec. A Lehigh Valley shock source and scrambler model No. 1311 was set to deliver a shock of $680 \mathrm{~V}$ through the grid floor. Manual push buttons controlled the various stimuli. Response latencies were recorded to the nearest .01 sec on Standard electric timers.

\section{Procedure}

The rats were deprived of food for $12 \mathrm{~h}$ before being given wet mash containing elther tragacanth or magnesium pemoline $(10 \mathrm{mg} / \mathrm{kg})$ suspended in tragacanth. Thirty minutes after receiving the mash, the animals were run for 150 discrimination trials by the $E$ who was ignorant of the drug received by the animal. There were 75 shock trials randomly mixed with 75 non-shock trials, counterbalanced within blocks of 10 trials using Gellerman orders. Half of the animals had shock paired with buzzer (buzzer $=\mathrm{CS}^{+}$) and non-shock paired with light (light $=\mathrm{CS}^{-}$); the other half had the significance of the stimuli reversed. The positive or negative conditioned stimulus began as soon as the animal was placed in the box. On shock trials $\left(\mathrm{CS}^{+}\right)$, shock began $15 \mathrm{sec}$ later, and the trial was terminated at $20 \mathrm{sec}$ or when the rat jumped onto the escape platform. On non-shock trials $\left(\mathrm{CS}^{-}\right)$, the latency of the first jump at the escape platform (which was blocked by the Plexiglas door) was recorded, and the trial continued for the full $20 \mathrm{sec}$ when the stimulus and trial were terminated. Every fifth nonshock trial (a total of 15) was a test trial when the negative conditioned stimulus was on, but the Plexdglas door was not in place. The CS was terminated whenever S made a successful response.

\section{Resulis and Discussion}

Figure 1 shows the mean response latencies of drug and control animals, plotted separately according to the stimulus serving a $\mathrm{CS}^{+}$. The data are the latencies from the fifth $\mathrm{CS}^{+}$trial and the single $\mathrm{CS}^{-}$test trial within each block of 10 trials. It is clear that when the buzzer served as $\mathrm{CS}^{+}$both groups gave faster latencies to $\mathrm{CS}^{+}$ than to $\operatorname{CS}-(F=194.1, d f=1 / 16, p<.01)$. However, the drug had no effect upon this differential performance; an analysis of variance revealed no interaction between drug and the two kinds of trials. When light served as $\mathrm{CS}^{+}$, however, the non-drug animal responded with faster latencies to $\mathrm{CS}^{+}$, but the drug animals failed to 


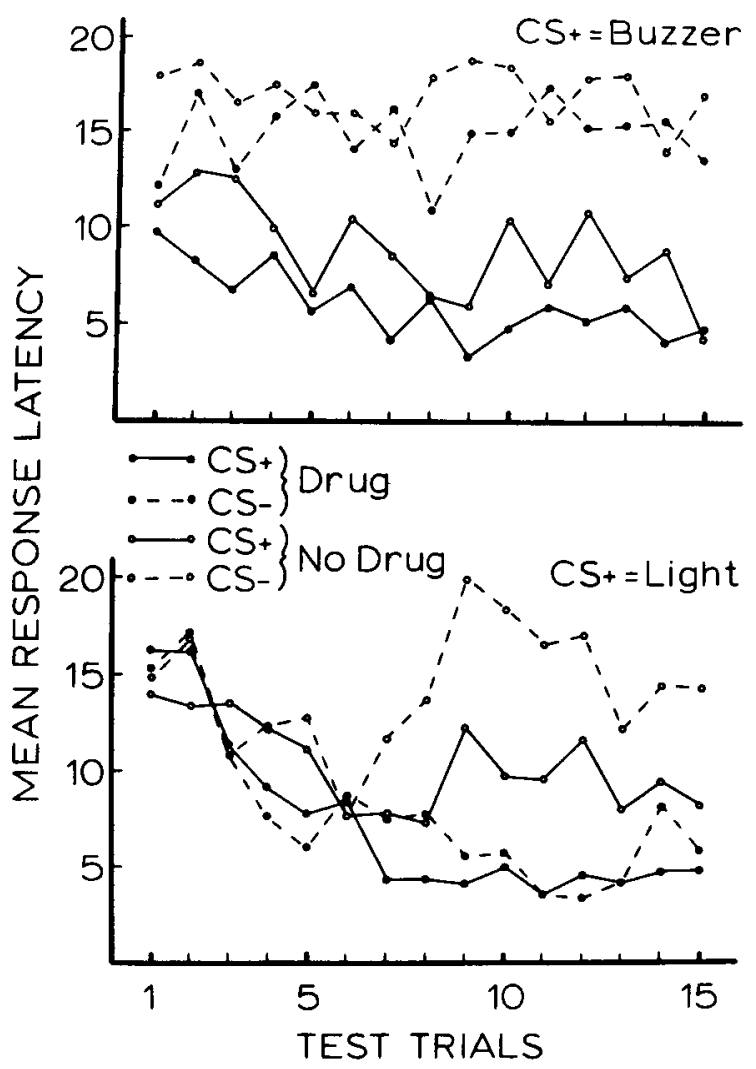

Fig. 1.

discriminate; this appears as a significant interaction between drug and kind of trial $(F=7.28, d f=1 / 16, p<$ $.05)$. The failure of the drug animals to discriminate when light is $\mathrm{CS}^{+}$resulted from a continued tendency to respond rapidly to the buzzer $\mathrm{CS}^{-}$.

Magnesium pemoline also tended to lower all response latencies. The mean overall latency for the drug animals was $9.0 \mathrm{sec}$, that for the non-drug animals $12.6 \mathrm{sec}$; this difference is reliable $(F=5.78, d f=1 / 16, p<.05)$.

There is no evidence in these data that magnesium pemoline produced superior learning. The discrimination performance of non-drug animals was either equal (when buzzer was $\mathrm{CS}^{+}$) or superior (when light was $\mathrm{CS}^{+}$) to that of drug animals. The drug did produce generally shorter response latencies, but this only resulted in faster response to the buzzer when it served as $\mathrm{CS}^{-}$ and therefore inferior discrimination.

These findings support the results of Plotnikoff(1966) and Kulkarni (1967) in the sense that magnesium pemoline produced shorter response latencies to $\mathrm{CS}^{+}$. However, the finding that response latencies were also shorter to $\mathrm{CS}^{-}$calls into question their interpretation of these results as an enhancement of learning. These data suggest that magnesium pemoline, rather than enhancing learning, increases activity or sensitivity to external stimuli. This sensitivity increase seems particularly large for auditory stimuli, such as those used in previous reports of positive findings.

The results of this experiment are congruent, however, with the findings of Beach \& Kimble (1967) that magnesium pemoline results in a more sustained sensitivity to a buzzer and the finding by Gurowitz et al (1967) of a deficit in passive avoidance due to magnesium pemoline.

\section{References}

BEACH, G., \& KIMBLE, D. P. Activity and responsivity in rats after magnesium pemoline injections. Science, 1966, 155, 698-701.

GLASKY, A. J., \& SIMON, L. N. Magnesium pemoline: Enhancement of brain RNA polymerases. Science, 1966, 151, 702-703.

GUROWITZ, E. M., LUBAR, J. F., AIN, B. R., \& GROSS, D. A. Disruption of passive avoidance learning by magnesium pemoline. Psychon Sci., 1967, 8, 19-20.

KULKARNI, A. S. Magnesium pemoline: Facilitation of instrumental avoidance learning. Psychon. Sci, 1967, 9, 39-40.

LUBAR, J. F., BOITANO, J. J., GUROWITZ, E. M., \& AIN, B. R. Enhancement of performance in the Hebb-Williams maze by magnesium pemoline. Psychon. Sci, 1967, 7, 381-382.

PLOTNIKOFF, N. Magnesium pemoline: Enhancement of learning and memory of a conditioned avoidance response. Science, 1966, 151, 703-704.

POWELL, B. J., MARTIN, L. K., \& KAMANO, D. K. Magnesium pemoline: Effects on training vs. testing of an avoidance response. Psychon. Sci., 1967, 8, 205-206.

POWELL, B. J., MARTIN, L. K., \& KAMANO, D. K. More on magnesium pemoline: Differential effects of advance and immediate injections on avoidance performance. Psychon. Sci, 1967, 8, 303-304.

Notes

1. This investigation was supported in part by NSF Grant GB-6493 to Yale University. The first author was an NSF undergraduate research participant under Grant GY-2758 during this project; the second author supervised the research. Abbott Laboratories kindly provided the magnesium pemoline.

2. Now at the University of Texas. 